\title{
Review
}

\section{Caffeine analogs: biomedical impact}

\author{
J. W. Daly \\ Laboratory of Bioorganic Chemistry, National Institute of Diabetes and Digestive and Kidney Diseases, \\ National Institutes of Health, DHHS, Bethesda, Maryland 20892-0820 (USA), Fax:+1301402 0008, \\ e-mail: jdaly@nih.gov
}

Received 31 January 2007; received after revision 7 April 2007; accepted 26 April 2007

Online First 18 May 2007

\begin{abstract}
Caffeine, widely consumed in beverages, and many xanthine analogs have had a major impact on biomedical research. Caffeine and various analogs, the latter designed to enhance potency and selectivity toward specific biological targets, have played key roles in defining the nature and role of adenosine receptors, phosphodiesterases, and calcium release channels in physiological processes. Such xanthines and other caffeine-inspired heterocycles now provide
\end{abstract}

important research tools and potential therapeutic agents for intervention in Alzheimer's disease, asthma, cancer, diabetes, and Parkinson's disease. Such compounds also have activity as analgesics, antiinflammatories, antitussives, behavioral stimulants, diuretics/natriuretics, and lipolytics. Adverse effects can include anxiety, hypertension, certain drug interactions, and withdrawal symptoms.

Keywords. Adenosine receptor, caffeine, calcium, GABA receptor, phosphodiesterase, xanthine.

The stimulant properties of infusions prepared from coffee beans or tea leaves undoubtedly play a significant role in the worldwide popularity of such beverages and of cola drinks to which caffeine is added as a flavor enhancer [1]. Caffeine, the major behavioral stimulant present in coffee, was isolated in 1820 and the correct structure of this methylxanthine was finally established in the last decade of that century. However, the targets underlying the behavioral stimulant properties of methylxanthines, such as caffeine, were not clearly recognized until 1981, when correlations of the stimulant properties of caffeine and various analogs were correlated with the blockade of adenosine receptors [2]. The behavioral depression elicited by high dosages of caffeine and by some xanthine analogs was proposed to be due to inhibition of cyclic nucleotide phosphodiesterases $[2,3]$. Ligands for adenosine receptors were clearly targets for drug development [4] as were inhibitors for phosphodiesterase [5]. The biological effects of caffeine are now known to span a wide range of molecular targets [6], the most important of which are the following: i) adenosine receptors, where xanthines act as antagonists; ii) phosphodiesterases, where xanthines act as inhibitors; iii) calcium release ryanodine-sensitive channels in the sarcoplasmic and endoplasmic reticulum, where xanthines act to sensitize the channels to the activation by calcium. iv) $\mathrm{GABA}_{\mathrm{A}}$ receptors, where xanthines act as antagonists at the benzodiazepine-positive modulatory site. There are many further biological targets at which caffeine and analogs can act, but those require millimolar concentrations of caffeine [For coverage of such targets see refs 6, 7].

Caffeine itself is a rather unique compound with very high solubility in both water and nonpolar organic solvents. It partitions readily across cell membranes, rapidly yielding high levels throughout the body, 


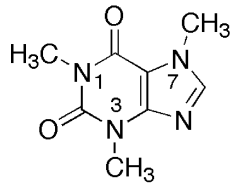

Caffeine

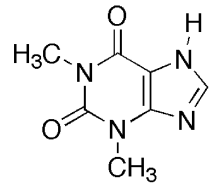

Theophylline

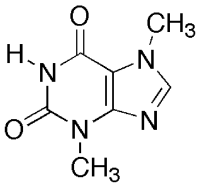

Theobromine<smiles>Cn1c(=O)[nH]c2ncn(C)c2c1=O</smiles>

Paraxanthine

Figure 1. The natural methylxanthines.

including the brain [8]. Elimination in vivo is virtually entirely dependent on metabolism to more polar entities. Metabolism in humans leads to paraxanthine, a xanthine sharing many of the biological activities of caffeine [2]. The presence of paraxanthine in coffee beans was reported in 1980 [9]. Theophylline, another metabolite of caffeine and a significant xanthine in tea leaf infusions, also shares the biological activities of caffeine [2]. Theobromine, the third well-known natural xanthine, is present in chocolate derived from cacao beans. It is a weak adenosine antagonist and only a weak central stimulant [2]. Caffeine also is present in cacao beans, but in much lower amounts. The structures of the three major natural methylxanthines and of paraxanthine are shown in Figure 1. The various activities of caffeine have led to its extensive use as a research tool and as a starting point for the design and synthesis of a wide variety of xanthine and related heterocyclic analogs as antagonists at adenosine receptors and as inhibitors of phosphodiesterases.

\section{Adenosine receptors}

In 1969/1970, the stimulatory effects of adenosine on the generation of cyclic AMP in brain slices and the blockade of that effect by caffeine were reported [10, 11]. That the depressant effects of adenosine in heart could be blocked by caffeine had been reported a few years earlier[12]. Then in 1978, Burnstock [13] formulated the existence of two classes of purinergic receptors, namely the $\mathrm{P}_{1^{-}}$(adenosine) and the $\mathrm{P}_{2^{-}}$ (ATP) receptors. Methylxanthines blocked the $\mathrm{P}_{1^{-}}$ receptors, while having no effect on the $\mathrm{P}_{2}$-receptors. Functional studies in the late 1970s/early 1980s provided evidence that the $\mathrm{P}_{1}$-receptors could be divided into $\mathrm{A}_{1}$-adenosine receptors that were inhibitory to adenylate cyclase and $\mathrm{A}_{2}$-adenosine receptors that were stimulatory to adenylate cyclase $[14,15]$ and then that the $\mathrm{A}_{2}$-adenosine receptors could be divided into $\mathrm{A}_{2 \mathrm{~A}}$-receptors with high affinities for agonists and $\mathrm{A}_{2 \mathrm{~B}}$-receptors with low affinity for agonists $[16,17]$. Another low-affinity adenosine receptor, the $\mathrm{A}_{3^{-}}$ receptor, was introduced in 1992 [18]. The $\mathrm{A}_{3^{-}}$ adenosine receptor, like the $\mathrm{A}_{1}$-receptor, was not only inhibitory to adenylyl cyclase, but could also stimulate phospholipase $\mathrm{C}$, thereby triggering through generation of $\mathrm{IP}_{3}$ a calcium signal [19]. The existence of several adenosine receptor subtypes, all sensitive to blockade by xanthines, generated extensive development of agonists and selective and potent xanthineinspired antagonists. The therapeutic potential for both adenosine receptor agonists and antagonists and the diversity of such synthetic agents was highlighted for $\mathrm{A}_{1}$ - and $\mathrm{A}_{2}$-receptors in 1992 [20], for $\mathrm{A}_{3}$-receptors in 2000 [21], for all adenosine receptors in 1996 [22] and for adenosine antagonists in 2001 [23]. There have been extensive reviews on adenosine receptor agonists, antagonists, and positive modulators and on possible therapeutic targets. These include, from 2006, reviews focusing on adenosine receptors as therapeutic targets [24], adenosine receptor antagonists as potential therapeutics [25], antagonists for $A_{1}$ - and $\mathrm{A}_{2 \mathrm{~A}}$-receptors [26], antagonists for $\mathrm{A}_{2 \mathrm{~B}}$-receptors and potential therapeutic applications [27], ligands for $\mathrm{A}_{2 \mathrm{~B}}$-receptors [28, 29], adenosine receptor ligands as antiinflammatories [30], and purines as effectors of adenosine receptors and other biological targets [31]. Thus, the present section on adenosine receptors attempts only to highlight certain xanthines as selective and/or potent antagonists of adenosine receptors. The affinities of the xanthines highlighted in Figures 2-5 for $\mathrm{A}_{1^{-}}, \mathrm{A}_{2 \mathrm{~A}^{-}}, \mathrm{A}_{2 \mathrm{~B}^{-}}$and $\mathrm{A}_{3}$-adenosine receptors are presented in Table 1.

\section{$\mathbf{A}_{\mathbf{1}}$-receptors}

A range of xanthines selective and potent as antagonists for $\mathrm{A}_{1}$-adenosine receptors have been developed [24-26]. Many of the $A_{1}$-selective xanthines are characterized by large substituents, such as a phenyl or cycloalkyl moiety, in the 8-position and by propyl groups in the 1- and 3-position (see DPCPX, KW3902, and CVT 124 in Fig. 2). A carboxyl moiety in BG 9928 (see Fig. 2) improved water solubility and oral efficacy [32]. Introduction of an ionized sulfonic acid moiety on the 8-phenyl ring resulted in an $\mathrm{A}_{1}$ selective antagonist, with only peripheral effects (see DPSPX in Fig. 2). The presence of polar moieties in the 1-, 3- or 7-alkyl substituents greatly reduced or abolished antagonist activity at adenosine receptors [33]. However, certain xanthines, such as propentofylline and pentoxifylline, with polar moieties in the 1substituent (see Fig. 6), inhibit adenosine uptake [34, 35 ], thereby potentiating the effects of endogenous 
Table 1. Affinities of xanthine antagonists for adenosine receptors.

\begin{tabular}{|c|c|c|c|c|}
\hline Agent & $\begin{array}{l}\mathrm{Ki} \text { (nanomolar) } \\
\mathrm{A}_{1}\end{array}$ & $\mathrm{~A}_{2 \mathrm{~A}}$ & $\mathrm{~A}_{2 \mathrm{~B}}$ & $\mathrm{~A}_{3}$ \\
\hline \multicolumn{5}{|l|}{$A_{1}$ selective } \\
\hline DPCPX & 3.4 & 130 & 50 & 4000 \\
\hline KW-3902 & $0.19^{*}$ & $170^{*}$ & - & - \\
\hline CVT-124 & 36 & 2800 & 760 & 20000 \\
\hline BG 9928 & 7.0 & 6400 & 430 & $>10000$ \\
\hline DPSPX & $140^{*}$ & $790 *$ & 250 & 180 \\
\hline $\mathrm{XAC}$ & 6.8 & 18 & 16 & 26 \\
\hline Triazole I & 1.4 & $420 *$ & - & - \\
\hline Triazole II & 2.6 & - & - & - \\
\hline Triazole III & 22 & 4400 & 580 & $>10000$ \\
\hline \multicolumn{5}{|l|}{$\mathrm{A}_{2 \mathrm{~A}}$ selective } \\
\hline DMPX & 45000 & 16000 & - & - \\
\hline $\mathrm{CSC}$ & $2800 *$ & $54 *$ & - & - \\
\hline KW-6002 & $580^{*}$ & $13^{*}$ & - & - \\
\hline KF 17837 & 62 & $1 *$ & & \\
\hline \multicolumn{5}{|l|}{$\mathrm{A}_{2 \mathrm{~B}}$ selective } \\
\hline Enprofylline & 160000 & 32000 & 7000 & 65000 \\
\hline IPDX & 24000 & 36000 & 630 & 53000 \\
\hline PBS 1115 & $>10000$ & $24000 *$ & 53 & $>10000$ \\
\hline MRS 1754 & 400 & 500 & 2.0 & 570 \\
\hline CVT-5440 & $>10000$ & $>5000$ & 50 & 8400 \\
\hline MRE 2030F20 & $>1000$ & $>1000$ & 12 & $>1000$ \\
\hline 8-PyrazolylX & 100 & 1500 & 22 & 1200 \\
\hline \multicolumn{5}{|l|}{$\mathrm{A}_{3}$ selective } \\
\hline Xanthine I & $>10000$ & 240 & - & 4.2 \\
\hline PSB-11 & 1600 & 1300 & - & 2.3 \\
\hline OT-7999 & $>10000$ & $>10000$ & $>10000$ & 0.95 \\
\hline Pyrrolopurine & $>1000$ & $>1000$ & $>1000$ & 0.8 \\
\hline MRE 3008F20 & 1100 & 140 & 2100 & 0.85 \\
\hline
\end{tabular}

Ki values from the literature $[23-29,48,56-58]$ are for inhibition of binding of ligands to $\mathrm{A}_{1^{-}}, \mathrm{A}_{2 \mathrm{~A}^{-}}, \mathrm{A}_{2 \mathrm{~B}^{-}}$, and $\mathrm{A}_{3}$-adenosine receptors of human or, when marked with an asterisk, of rat origin. For structures see Figures 2-8.

adenosine rather than blocking the activation of adenosine receptors. A functionalized congener approach to the moiety at the 8-position has resulted in a variety of xanthine antagonists [36] (see XAC in Fig. 2). A logical extension of structural alterations to the caffeine template was replacement of the xanthine ring system with other electron-rich heterocycles [see refs 25,26$]$. Several have potent and/or selective antagonist activity at $\mathrm{A}_{1}$-adenosine receptors. For example, three of the so-called extended xanthines (see triazolopurine I, II, and III in Fig. 2) have high potency and selectivity as $\mathrm{A}_{1}$-antagonists [see refs 23 , $25,37]$.

\section{$\mathbf{A}_{2 \mathrm{~A}}$-Receptors}

The selectivity of caffeine analogs for $\mathrm{A}_{2 \mathrm{~A}}$-adenosine receptors was somewhat increased by the replacement of one or two methyl groups of caffeine with a propyl or propargyl substituent [38]. Indeed, 3,7-dimethyl-1propargylxanthine [39] (see DMPX in Fig. 3) has been used as a selective $\mathrm{A}_{2}$-antagonist, despite only modest selectivity. The presence of a 8-cycloalkyl substituent in caffeine modestly increased selectivity for $\mathrm{A}_{2}$ receptors [40]. Ultimately, 8-styrylxanthine analogs proved to be useful, highly selective $\mathrm{A}_{2 \mathrm{~A}}$-receptor antagonists [41-43] (see CSC, KW-6002 and KF17837 in Fig. 3). A variety of other 8-styrylxanthines selective for $\mathrm{A}_{2 \mathrm{~A}}$-receptors have been developed [44, 45]. The first nonxanthine to be developed as an $\mathrm{A}_{2 \mathrm{~A}^{-}}$ selective antagonist was a trizoloquinazoline, CGS 15943 [46]. Subsequently, a wide range of such heterocycles have been developed with selectivity as antagonists of $\mathrm{A}_{2 \mathrm{~A}}$-receptors [see refs 25,26 and references therein].

\section{$\mathbf{A}_{2 \mathrm{~B}}$-Receptors}

There is currently great interest in antagonists selective for $\mathrm{A}_{2 \mathrm{~B}}$-adenosine receptors [27-29]. Enprofylline with a 1-propyl substituent (see Fig. 4) represents a lead xanthine with selectivity toward the $\mathrm{A}_{2 \mathrm{~B}^{-}}$ receptor [47]. Remarkably, an 8-substituted 3-isobutylxanthine (see IPDX in Fig. 4) proved very selective for $\mathrm{A}_{2 \mathrm{~B}}$-receptors [48]. A series of 1-propylxanthines with 8-phenyl moieties [43] yielded the highly $\mathrm{A}_{2 \mathrm{~B}^{-}}$ selective antagonist 1-propyl-8- $p$-sulfophenylxanthine PBS 1115 [49] (see Fig. 4), which would be active only peripherally. A series of 1,3-dipropylxanthines with functionalized 8-phenyl moieties yielded 


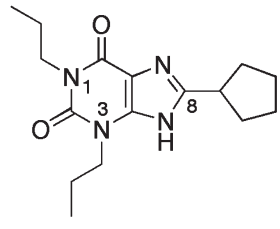

DPCPX

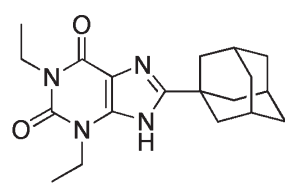

KW-3902

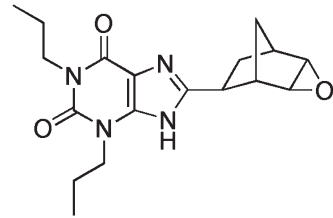

CVT-124<smiles>CCCn1c(=O)c2nc(C34CCC(CCC(=O)O)(CC3)C4)[nH]c2n(CCC)c1=O</smiles>

BG 9928

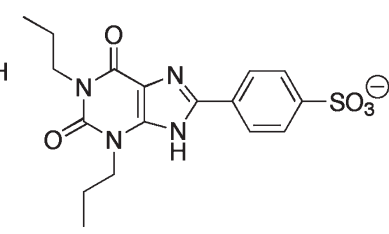

DPSPX

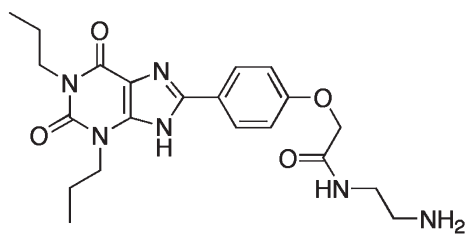

XAC<smiles>CCCn1c2[nH]c(C3CCCC3)nc2c(=O)n2nc(Cc3ccccc3)nc12</smiles>

Triazolopurine I
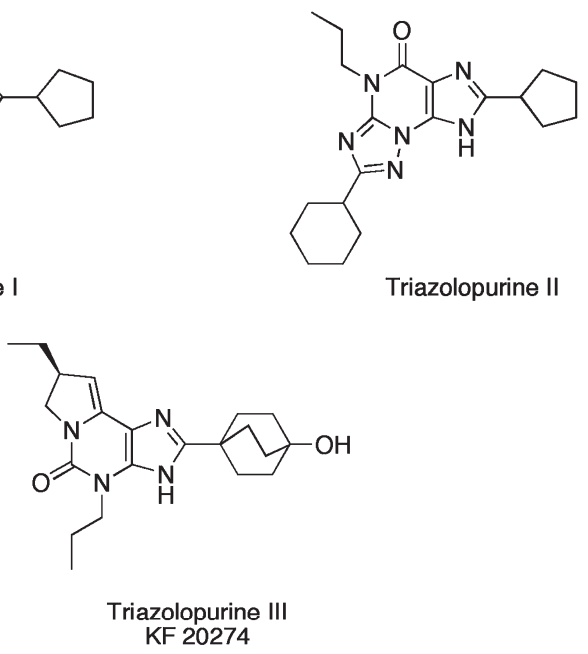

Figure 2. $A_{1}$-adenosine receptor antagonists. $X A C$ is very $A_{1}$ selective in rat, but not in human [see ref. 25].

MRS 1754, (see Fig. 4), a highly $\mathrm{A}_{2 \mathrm{~B}}$-selective antagonist [50]. Further development provided CVT-5440 [51], another $A_{2 B}$-selective antagonist (see Fig. 4). Further xanthines in which a substituted 8-pyrazolo ring replaced the substituted 8-phenyl ring of MRS 1754 provided $\mathrm{A}_{2 \mathrm{~B}}$-selective antagonists MRE 2030F20 and an 8-pyrazolylxanthine [52, 53] (see Fig. 4). Caffeine-inspired nonxanthine heterocyclic antagonists for $\mathrm{A}_{2 \mathrm{~B}}$-adenosine receptors have also been developed (see refs. 25, 27, 29, 30]. These include a variety of 9-deaza-xanthines and 9-deaza-adenines.

\section{$\mathbf{A}_{3}$-Receptor}

The $\mathrm{A}_{3}$-adenosine receptors of rats show relatively low affinities for caffeine, theophylline and other xanthines, while those of humans show somewhat higher affinities [21, 54]. An unusual 3-benzylxanthine (see xanthine I, Fig. 5) has high affinity and selectivity for $\mathrm{A}_{3}$-receptors [55]. In addition, so-called extended xanthines, such as PSB-11 [56], the triazolopurine OT7999 [57] and a pyrrolopurine [58] (see Fig. 5) have high affinity and selectivity for $\mathrm{A}_{3}$-receptors. A pyrazolo-triazolo-pyrimidine, MRE 3008F20 (see Fig. 5) has been introduced as a radioligand for $\mathrm{A}_{3^{-}}$ adenosine receptors [59]. Other polyheterocyclic analogs have been introduced as $\mathrm{A}_{3}$-receptor antagonists as have flavonoids, dihydropyridines, pyridines, thiazoles, and adenosine analogs [see refs 24, 25].

\section{Cyclic nucleotide phosphodiesterases}

The discovery and isolation of a cyclic nucleotide phosphodiesterase was hastened by the finding that caffeine appeared to enhance the formation of cyclic AMP by the newly discovered enzyme adenylyl cyclase [60]. The three naturally occurring methylxanthines, namely caffeine, theophylline, and theo- 
<smiles>C#CCn1c(=O)c2nc[nH]c2n(C)c1=O</smiles>

DMPX<smiles>Cn1c(=O)c2c(nc(C=Cc3cccc(Cl)c3)n2C)n(C)c1=O</smiles>

CSC<smiles>CCCn1c(=O)c2c(nc(/C=C/c3ccc(OC)c(OC)c3)n2C)n(CCC)c1=O</smiles>

KW-6002 (Istradefylline)

Figure 3. $\mathrm{A}_{2 \mathrm{~A}}$-adenosine receptor antagonists.

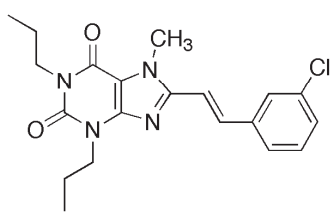

KF17837 bromine, were relatively weak competitive inhibitors [61], and xanthines with substituents other than methyl were prepared in efforts to enhance potency [5]. Attempts were made to correlate potencies of xanthines as phosphodiesterase inhibitors and pharmacological effects, such as lipolytic effects in adipocytes [62], relaxant effects on tracheal smooth muscle [63], contraction of striated muscle [64], and anxiogenic effects [65]. It was clear that other effects of xanthines on adenosine receptors, calcium release, and perhaps prostaglandin synthesis confounded any interpretations. Indeed, the lipolytic effects of xanthines were shown to be due to blockade of the $A_{1}$ adenosine receptors that were inhibitory to adenylyl cyclase [66].

3-Isobutyl-1-methylxanthine (IBMX, see Fig. 6) became established as a potent phosphodiesterase inhibitor that, however, was even more potent as an adenosine receptor antagonist [3]. The phosphodiesterase isozymes (PDEs) were found to be expressed to<smiles>CCCn1c(=O)[nH]c(=O)c2nc[nH]c21</smiles>

Enprofylline<smiles>CC(C)Cn1c(=O)[nH]c(=O)c2nc(N3CCCC3)[nH]c21</smiles>

IPDX<smiles>CCCn1c(=O)[nH]c2[nH]c(-c3ccc(S(=O)(=O)[O-])cc3)nc2c1=O</smiles>

PBS 1115<smiles>CCCn1c(=O)c2nc(-c3ccc(OCC(=O)Nc4ccc(C#N)cc4)cc3)[nH]c2n(CCC)c1=O</smiles>

MRS 1754<smiles>CCCn1c(=O)c2nc(-c3cc(OCC(=O)Nc4ccc(OC)c(OC)c4)nn3C)[nH]c2n(CCC)c1=O</smiles>

MRE 2030F20<smiles>CCCn1c(=O)c2nc(-c3ccc(OCc4noc(-c5cccc(OC)c5)n4)cc3)[nH]c2n(CCC)c1=O</smiles>

CVT-5440<smiles>CCCn1c(=O)c2nc(-c3cnn(CC(=O)Nc4ccccc4Cl)c3)[nH]c2n(CCC)c1=O</smiles>

8-Pyrazolylxanthine

Figure 4. $\mathrm{A}_{2 \mathrm{~B}}$-adenosine receptor antagonists. 
<smiles></smiles>

Xanthine I

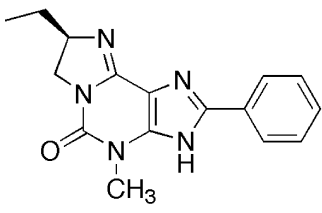

PSB-11

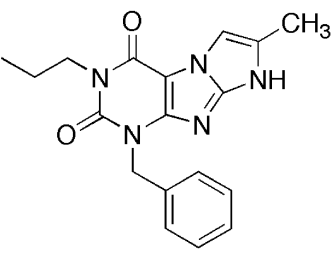

Pyrrolopurine

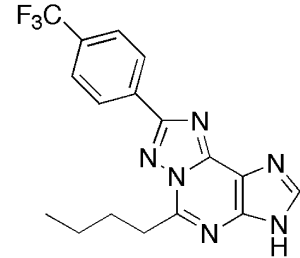

Triazolopurine OT-7999

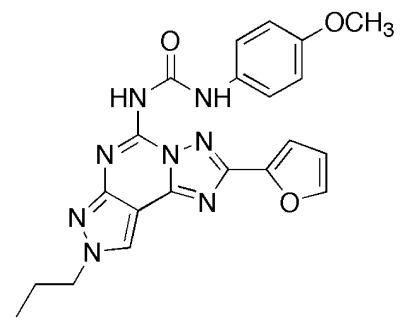

MRE 3008F20
Figure 5. $A_{3}$-adenosine receptor antagonists.

varying degrees in different tissues and the goal became the discovery of isozyme-selective agents [67]. 3-Isobutyl-1-methylxanthine (IBMX) proved relatively unselective toward five of the isozymes [68]. However, a recent report indicated that IBMX has no effect on PDE8 [69]. Extensive pioneering studies on alkylxanthines by Wells and colleagues [70, 71] led to xanthines with some selectivity, namely 3isobutyl-1-isoamylxanthine (IIX, see Fig. 6) toward PDE4 and 8-methoxymethylIBMX (8- $\mathrm{MeOCH}_{2}-$ IBMX, see Fig. 6) toward PDE1 [63]. IIX was relatively weak as an antagonist at adenosine receptors [72, 73]. Alkylxanthines that were potent inhibitors of PDE4 all appeared to be behavioral depressants $[3,72]$.

There are now at least 12 PDEs [74, 75]. The therapeutic potential of selective phosphodiesterase inhibitors has been reviewed frequently over the past three decades. Two such reviews appeared in 2005 [76, 77]. Because multiple isozymes often occur in the same cell type and because there are few if any specific inhibitors, therapeutic targeting remains difficult. The following are broad generalizations for inhibitor targets: antiinflammatory, asthma treatment, and immunosuppressant (PDE3, 4); angina, hypertension, and cardiac failure (PDE2,3); antithrombotic
(PDE4); vasodilation, hypertension, and erectile dysfunction (PDE5); and vascular relaxant (PDE1) [see refs 31, 74-77].

Unlike the adenosine receptor field where most antagonists owe their origin to caffeine/theophylline as lead compounds, most of the current phosphodiesterase inhibitors are not derived from xanthines [see refs 76, 77]. As mentioned above, IIX and 8- $\mathrm{MeOCH}_{2}-$ IBMX are somewhat selective for PDE4 and PDE1, respectively. Denbutylline, doxofylline, and arofylline are somewhat selective for PDE4, and KMUP-1 [78] for PDE3, 4, while pentoxifylline and propentofylline are characterized as weak PDE4 inhibitors (for structures see Fig. 6). A variety of other xanthines ( $R$-lisofylline, isobufylline, torbaphylline, bamiphylline and furafylline) have been introduced, some with antiinflammatory activity. The extended xanthine SCH51866 (PDE1) [79], the extended 8-MeO-xanthine (PDE5) [80] and an 8-m-sulfamidophenylxanthine (PDE5) [81] have been developed (see Fig. 6 for structures). Finally, zaprinast, analogous to a 2-phenylhypoxanthine (see Fig. 6) and selective for PDE1 and PDE5, represented a lead structure for development of sildenafil for erectile dysfunction [82]. A number of ring-extended xanthines with nanomolar potency at PDE5 have now been developed [see refs 80, 81]. Many of the xanthines that inhibit phosphodiesterases are also antagonists at adenosine receptors and block adenosine uptake [see refs $7,34,35]$.

\section{Calcium release}

Caffeine continues to be widely used as a research tool to elicit release of intracellular calcium through activation in consort with calcium of the ryanodinesensitive calcium release channels of the endoplasmic and sarcoplasmic reticulum [see ref 7]. Decades ago caffeine had been found to cause muscle contractures through release of intracellular calcium [83, 84]. Caffeine at the millimolar concentrations required to cause activation of ryanodine-sensitive calcium channels has many other effects on calcium homeostasis [see ref. 7] and hence cannot be used as a selective research tool for activation of ryanodinesensitive channels. Reports on inhibition of $\mathrm{IP}_{3^{-}}$ elicited calcium release by caffeine have appeared [85-87], and enhancement of capacitative calcium entry by caffeine has been reported [88, 89].

There have been only a few studies on structureactivity relationships for the efficacy/potency of xanthines in affecting intracellular or intravesicular calcium [90-92]. In human pheochromocytoma cells, two xanthines, 1-propyl- and 1-propargyl-theobro- 
<smiles>CC(C)Cn1c(=O)n(C)c(=O)c2nc[nH]c21</smiles>

IBMX<smiles>CC(C)CCn1c(=O)c2nc[nH]c2n(CC(C)C)c1=O</smiles>

IIX<smiles>COCc1nc2c(=O)n(C)c(=O)n(CC(C)C)c2[nH]1</smiles>

8- $\mathrm{MeOCH}_{2}-\mathrm{IBMX}$<smiles>CCCCCn1c(=O)c2c(ncn2CC(C)=O)n(CCCC)c1=O</smiles>

Denbutylline<smiles>Cn1c(=O)c2c(ncn2CC2OCCO2)n(C)c1=O</smiles>

Doxofylline<smiles>CCCn1c(=O)c2c(C)ncnc2n(-c2ccc(Cl)cc2)c1=O</smiles><smiles>[R]c1ccc(N2CCN(CCn3cnc4c3c(=O)n(C)c(=O)n4C)CC2)c([R])c1</smiles>

KMUP-1 $\mathrm{R}=\mathrm{Cl} \mathrm{R}^{\prime}=\mathrm{H}$ KMUP-3 $\mathrm{R}=\mathrm{H}^{\prime} \mathrm{R}^{\prime}=\mathrm{NO}_{2}$<smiles>CC(=O)CCCCn1c(=O)c2c(ncn2C)n(C)c1=O</smiles><smiles>CCCn1cnc2c1c(=O)n(CCCCC(C)=O)c(=O)n2C</smiles><smiles>CC(O)CCCCn1c(=O)c2c(ncn2C)n(C)c1=O</smiles><smiles>CC(C)Cn1cnc2c1c(=O)n(C)c(=O)n2C</smiles>

Pentoxifylline

Propentofylline

R-Lisofylline

Isbufylline<smiles>CCOCn1cnc2c1c(=O)n(CCCCC(C)(C)O)c(=O)n2C</smiles>

Torbaphylline<smiles>CCN(CCO)CCn1c(Cc2ccccc2)nc2c1c(=O)n(C)c(=O)n2C</smiles>

Bamiphylline<smiles>Cc1nc2c(=O)n(C)c(=O)n(Cc3ccco3)c2[nH]1</smiles>

Furafylline<smiles>CN1C(=O)c2nc(Cc3ccc(C(F)(F)F)cc3)[nH]c2N2C1=N[C@@H]1CCC[C@@H]12</smiles>

SCH 51866<smiles>CCN1C(=O)c2c(nc(OC)n2Cc2ccc(O)c(Br)c2)N2CC(Cc3ccccc3)N=C12</smiles>

8-MeO-Xanthine<smiles>CCCOc1ccc(S(=O)(=O)N(C)CCN(C)C)cc1-c1nc2c(=O)n(C)c(=O)n(CC(C)C)c2[nH]1</smiles>

8-Phenylsulfamido-Xanthine<smiles>CCCOc1ccccc1-c1nc2[nH]nnc2c(=O)[nH]1</smiles>

Zaprinast

Figure 6. Phosphodiesterase inhibitors.

mine (see Fig. 7), were about fourfold more potent than caffeine [90]. In sea urchin eggs, a 7-oxoheptylxanthine (see Fig. 7) was about fourfold more potent than caffeine [91]. Caffeine enhances the binding of $\left[{ }^{3} \mathrm{H}\right]$ ryanodine to calcium-release channels [93]. In an extensive series of 30 xanthines, the most efficacious in enhancing $\left[{ }^{3} \mathrm{H}\right]$ ryanodine binding to vesicles of rabbit muscle sarcoplasmic reticulum [94] was 1-hexyltheobromine (see Fig. 7). Several other xanthines, including 1-propargyltheobromine were somewhat more efficacious at $1.5 \mathrm{mM}$ than caffeine. In a similar study with 35 xanthines, only 7-propyltheophylline (see Fig. 7) was slightly more efficacious at $10 \mathrm{mM}$ than caffeine [95]. It would appear unlikely that a xanthine much more potent and selective than caffeine for the ryanodine-sensitive calcium-release channel will be developed. 
<smiles>CCCn1c(=O)c2c(ncn2C)n(C)c1=O</smiles>

1-Propyl-Theobromine<smiles>C#CCn1c(=O)c2c(ncn2CCCCCC(C)=O)n(C)c1=O</smiles>

7-Oxoheptyl-Xanthine<smiles>C#CCn1c(=O)c2c(ncn2C)n(C)c1=O</smiles>

1-Propargyl-Theobromine<smiles>CCCCCCn1c(=O)c2c(ncn2C)n(C)c1=O</smiles>

1-Hexyl-Theobromine<smiles>CCCn1cnc2c1c(=O)n(C)c(=O)n2C</smiles>

7-Propyl-Theophylline

Figure 7. Calcium-releasing agents.

\section{$\mathrm{GABA}_{\mathbf{A}}$ receptors}

Caffeine is one of many compounds that interact with $\mathrm{GABA}_{\mathrm{A}}$ receptors. Such compounds include the alkaloid antagonist bicucculline, the picrotoxinin channel blockers, the barbiturates and steroids that increase channel open time, and the benzodiazepine allosteric positive modulators [96, 97]. There have been limited studies on xanthine interactions with $\mathrm{GABA}_{\mathrm{A}}$ receptors since the initial report in 1979 on the inhibition of $\left[{ }^{3} \mathrm{H}\right]$ diazepam binding by caffeine [98]. Conversely, at that time, diazepam was found to antagonize caffeine-induced convulsions [99]. Further studies indicated that caffeine and theophylline act as antagonists or perhaps reverse agonists at benzodiazepine sites, while also interacting with the picrotoxinin and GABA sites [see ref. 95]. A series of 23 xanthines has been studied for effects on the binding of ligands to the benzodiazepine and picrotoxinin sites of $\mathrm{GABA}_{\mathrm{A}}$ receptors in mouse cerebral cortical membranes [95]. Caffeine had an $\mathrm{IC}_{50}$ versus $\left[{ }^{3} \mathrm{H}\right]$ diazepam of $500 \mu \mathrm{M}$, while two xanthines, namely 1-propargyl-theobromine and 1,3-dipropargyl-7methylxanthine (see Fig. 8) were nearly fivefold more potent. However, both of these xanthines have relatively potent activity at adenosine receptors $[38$,

100] and activity similar to that of caffeine at phosphodiesterases [3] and at the ryanodine-sensitive calcium release channels [95]. Many of the xanthines at $1 \mathrm{mM}$ stimulated binding $\left[{ }^{35} \mathrm{~S}\right] \mathrm{TBPS}$ binding to the picrotoxinin site of the $\mathrm{GABA}_{\mathrm{A}}$ receptor, as did caffeine, while others had no effect or inhibited binding [95]. It would appear that prospects for developing a xanthine with potent and selective effects on $\mathrm{GABA}_{\mathrm{A}}$ receptors are poor.

A comparison of xanthines as blockers of GABA- and glycine-mediated chloride currents in rat hippocampal neurous indicated the caffeine was several-fold more potent against the glycine response $\left(\mathrm{IC}_{50}\right.$ $450 \mu \mathrm{M})$ than against the GABA response [101]. Theophylline had a similar potency to caffeine, while pentoxifylline (see Fig. 6) was twofold more potent than caffeine against the glycine response. Pentoxifylline was later shown to have potency similar to that of caffeine for inhibition of $\left[{ }^{3} \mathrm{H}\right]$ diazepam binding to $\mathrm{GABA}_{\mathrm{A}}$ receptors [95].

\section{Other targets}

There are many reports on other potential sites of action for caffeine [see refs 6,7]. These include several ion channels, neurotransmitter release, and various enzymes, but millimolar concentrations of caffeine are usually required. The effect for ion channels and enzymes is usually inhibitory. However, stimulation of the $\mathrm{Na} / \mathrm{K}$-ATPase by caffeine and theophylline occurs at millimolar concentrations [102] and an apparent activation of capacitative calcium entry [88, 89, 103] and calcium-activated potassium channels [104] by caffeine have been reported. Caffeine appeared to sensitize a Mg-ATPase to the stimulatory effects of calcium in cardiac myofibrils [105].

\section{Therapeutic prospects}

There are several major therapeutic targets toward which xanthines and heterocyclic xanthine analogs are<smiles>C#CCn1c(=O)c2c(ncn2C)n(C)c1=O</smiles>

1-Propargyl-Theobromine<smiles>C#CCn1c(=O)c2c(ncn2C)n(CC#C)c1=O</smiles>

1,3-Dipropargyl-Xanthine
Figure 8. $\mathrm{GABA}_{\mathrm{A}}$ receptor modulators. 
being directed. Some of the molecular targets for such xanthines are as follows:

1) Alzheimer's disease: $A_{2 A^{-}}$and $A_{2 B^{-}}$adenosine receptor antagonists;

2) Asthma - antiinflammatories: $A_{1^{-}}, A_{2 A^{-}}$, and $A_{2 B^{-}}$ adenosine receptor antagonists and phosphodiesterase inhibitors;

3) behavioral targets - antidepressant, anxiolytic, cognitive enhancement, neuroprotection: adenosine receptor antagonists and phosphodiesterase inhibitors;

4) cancer: G2 checkpoint inhibitors;

5) diabetes: $A_{2 B}$-adenosine receptor antagonists; phosphoenolpyruvate carboxykinase inhibitors; dipeptidyl peptidase IV inhibitors;

6) pain: $A_{2 A}$ - and $A_{2 B}$-adenosine receptor antagonists, phosphodiesterase inhibitors;

7) Parkinsonism: $A_{2 A}$-adenosine receptor antagonists, phosphodiesterase inhibitors;

8) renal effects - diuretics: $A_{1}$ - and $A_{2 A^{-}}$adenosine receptor antagonists;

9) respiratory targets - antitussives, apnea, chronic obstructive pulmonary disease, cystic fibrosis: adenosine receptor antagonists.

The following provides an overview of some of the current literature in these areas.

\footnotetext{
Alzheimer's disease

The consumption of caffeine-containing beverages appeared to possibly confer some protective effects from Alzheimer's disease [106]. In recent studies with model Alzheimer mice, chronic caffeine protected against cognitive impairment and resulted in reduced brain levels of $\beta$-amyloid protein [107]. In cortical neurons from model Alzheimer mice, the caffeine-elicited release of intracellular calcium was significantly greater than that in neurons from control mice [108]. A variety of therapeutic interventions are being explored for treatment of Alzheimer's disease; however, most of them involve cholinergic functions [109]. Nevertheless, $A_{2 B}$-adenosine receptor antagonists have been proposed as possible therapeutics for Alzheimer's disease [110]. Both caffeine and the selective nonxanthine $\mathrm{A}_{2 \mathrm{~A}^{-}}$ adenosine receptor antagonist ZM 241385 protected rat cerebellar neurons from the toxic effects of $\beta$ amyloid protein [111]. ZM 241385 is a triazolotriazine [112] related in structure to the widely used $\mathrm{A}_{2 \mathrm{~A}}$ receptor antagonist triazoloquinazoline CGS15943 [46]. The phosphodiesterase inhibitor propentofylline (see Figure 6) has cognitive-enhancing effects and thus might be beneficial for Alzheimer's disease [see however ref. 113].
}

\section{Asthma - Antiinflammatories}

The xanthines theophylline and enprofylline have been used therapeutically for asthma, and other agents that target $\mathrm{A}_{2 \mathrm{~B}}$-adenosine receptors are being sought for the treatment of asthma [see refs 114,115]. Asthma is a chronic inflammatory condition and caffeine and other xanthines, such as theophylline, pentoxifylline, and lisofylline (see Fig. 6), do have immunosuppressant effects and thus may have utility for autoimmune diseases [see ref. 116]. A recent review covers subtype selective adenosine receptor agonists and antagonists as antiinflammatory agents [30]. Other xanthines have been proposed to have potential for treatment of asthma, emphysema, and chronic bronchitis. These include CVT-5440 [117] and KMUP-3 [118] (see Figs 4, 6). Xanthines functionalized with alkylpiperazines in the 7-position of theophylline or the 3-position of theobromine were studied in 1985 as antihistaminics for the treatment of bronchospasm [119]. Activation of a nuclear enzyme poly(ADP-ribose)polymerase-1 appears to be associated with inflammatory diseases, and paraxanthine (see Fig. 1) was a relatively potent inhibitor, while caffeine was weak [120].

\section{Behavior targets - antidepressant - anxiolytic - cognitive enhancement - neuroprotection}

The behavioral stimulant properties of caffeine undoubtedly underlie the consumption of coffee and other caffeine-containing beverages by many individuals worldwide. Caffeine is perceived as increasing alertness and wakefulness, combating fatigue, and generally providing a sense of well-being. True addiction does not seem to occur although there are withdrawal symptoms [121]. At high doses and in certain individuals, unpleasant effects, including anxiety, occur. The molecular targets underlying the behavioral effects of caffeine have been extensively investigated, primarily in rodents. While blockade of adenosine receptors is clearly paramount in the behavioral effects of caffeine, the relative role of the subtypes remains under investigation [see ref. 122]. The dopaminergic reward system is closely involved [123]. The extensive on-going research on behavioral effects of caffeine and other xanthines and the implications for treatment of depression, anxiety, cognitive impairment, ischemic effects of stroke, and even drug dependency and schizophrenia is beyond the scope of the present overview [see ref. 124]. It should be noted that the acute and chronic effects of caffeine can be quite different [125]. Most of the central effects of caffeine at levels attained from beverages are due to blockade of adenosine receptors [121]. 


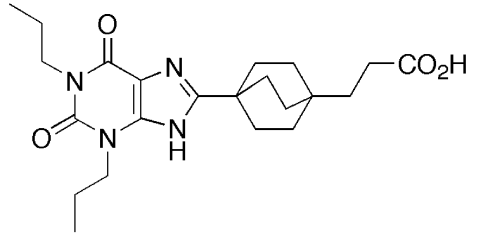

BG 9928

Congestive Heart Failure $\mathrm{A}_{1}$-Receptor Antagonist<smiles>CC(Cc1ccccc1)NCCn1cnc2c1c(=O)n(C)c(=O)n2C</smiles>

Fenetylline Central Stimulant<smiles>CCCCn1c(=O)n(Cc2ccccc2F)c(=O)c2nc(Cc3ccc(NC(C)=O)cc3)[nH]c21</smiles>
1,8-Dibenzyl-Xanthine PECPK Inhibitor Antidiabetic<smiles>CCCn1c(=O)c2c(nc(/C=C/c3ccc(OC)c(OC)c3)n2C)n(CCC)c1=O</smiles>

KW-6002 (Istradefylline)

Parkinson's Disease $\mathrm{A}_{2 \mathrm{~A}}$-Receptor Antagonist<smiles>Cn1c(=O)c2c(nc(C3CCCC(N)C3)n2Cc2ccccc2C#N)n(C)c1=O</smiles>

8-Piperidinyl-Xanthine DPP-IV Inhibitor Antidiabetic

Figure 9. Potential therapeutic xanthines.<smiles>Cc1noc(-n2cnc3c2c(=O)[nH]c(=O)n3C)n1</smiles>

$\mathrm{CH} 13584$

Antitussive<smiles>Cn1c(=O)c2c(nc3nc(NCCCN4CCN(c5ccccc5)CC4)c(Br)cn32)n(C)c1=O</smiles>

Arylpiperazine-Xanthine

Anxiolytic

Recent behavioral studies include that of the selective $\mathrm{A}_{2 \mathrm{~A}}$-receptor antagonist KW-6002 (see Fig. 3) [126]. Pentoxifylline and propentofylline (see Fig. 6) ameliorate brain ischemic effects in mice paradigms [127, 128]. The anxiolytic effects of an extended-ring xanthine, containing an arylpiperazine moiety (see Fig. 9) appears due to agonist activity at serotonin receptors [129]. A xanthine, fenetylline, containing an amphetamine moiety (see Fig. 9) has been used therapeutically in place of amphetamines [130] and now has become a drug of abuse. A recent report focused on the possibility that $\mathrm{A}_{2 \mathrm{~A}}$-receptor antagonists might be used in problems of addiction [131].

\section{Cancer}

There is extensive literature on the possible anticancer activity of caffeine and other xanthines [see ref. 132 and references therein]. Recently, the antimetastatic effects of caffeine in a mouse mammary tumor model were reported [133] as were further studies on the inhibition by caffeine of ultraviolet-induced skin tumors in hairless mice [134]. Caffeine is well-known to be an inhibitor of the $\mathrm{G} 2$ checkpoint for repair of damaged DNA [135]. In cancer cells defective for tumor suppressor protein $\mathrm{p} 53$, the G1 checkpoint for repair is defective. Thus, caffeine can enhance toxicity of tumor cells to DNA-damaging treatment by blocking the $\mathrm{G} 2$ checkpoint. Caffeine and a series of xanthines were assayed for $\mathrm{G} 2$ checkpoint inhibition 
[136]. However, even at millimolar concentrations most were inactive or less active than caffeine, with only 1-ethyl- and 1-propyl-theobromine being somewhat more active than caffeine. A number were cytotoxic.

\section{Diabetes}

$\mathrm{A}_{2 \mathrm{~B}}$-adenosine receptor antagonists have been suggested to have potential for treatment of type 2 diabetes [137], based on reported effects of adenosine receptor antagonists on glucose in rodents. Several relatively potent 1,8-dibenzyl-3-butyl- xanthines (see Fig. 9) were developed as inhibitors of phosphoenolpyruvate carboxykinase, the rate-limiting step in hepatic gluconeogenesis [138]. Several studies have indicated that the antiinflammatory xanthine lisofylline (see Fig. 6) has antidiabetic effects in a nonobese diabetic mouse model $[139,140]$ and has protective effects on pancreatic $\beta$-cells [see ref. 141 and references therein]. Pentoxifylline also has antidiabetic effects in the mouse model [142]. Attempts to correlate caffeine consumption and risk of type 2 diabetes have been inconsistent (see ref. 143 and refs. therein). Indeed, reports that caffeine ingestion caused a reduction in insulin-stimulated glucose uptake have appeared [143, 144]. Recently, a series of xanthines (see 8-piperidinyl-xanthine Fig. 9) and related heterocycles were introduced as potent and selective inhibitors of dipeptidyl peptidase IV, a clinically relevant target for treatment of type 2 diabetes [see ref. 145 and references therein].

\section{Pain}

Caffeine has a long history as an analgesic adjuvant $[146,147]$. Other adenosine receptor antagonists have antinociceptive effects with $\mathrm{A}_{2 \mathrm{~B}}$-receptors appearing to be the targets [148]. Some of the xanthines that are $\mathrm{A}_{2 \mathrm{~B}}$-antagonists and thus perhaps represent lead compounds are shown in Figure 4. There are a multitude of pathological and acute pain states and a variety of receptors, including opioid, adenosine, cannabinoid, galanin, GABA, glycine, vanilloid, and nicotinic receptors, and ion channels including sodium and calcium, that represent therapeutic targets [149151].

\section{Parkinson's disease}

The potential therapeutic treatment of Parkinson's diseases by $\mathrm{A}_{2 \mathrm{~A}}$-adenosine receptor antagonists has been the subject of recent comprehensive reviews [152-154]. A number of xanthines (CSC, KW 6002, KF17837, see Figs 3 and 9) and nonxanthines (MSX-2, SCH 58261, ZM241385 [25]) are under development as antiparkinsonism agents. All are selective for $\mathrm{A}_{2 \mathrm{~A}^{-}}$ receptors as is an 8-triazoyladenine, ST 1535, which represents another potential new agent [155]. However, $A_{2 \mathrm{~A}}$-receptor antagonists represent only one of several therapeutic approaches to Parkinson's disease [see ref. 156]. Selective inhibition of monoamine oxidase $\mathrm{B}$ represents another approach, and the $\mathrm{A}_{2 \mathrm{~A}^{-}}$ receptor antagonist 3-chlorostyrylcaffeine (CSC, see Fig. 3) was recently reported to be a potent inhibitor of that enzyme [157]. Caffeine consumption in beverages has been proposed to be associated with a reduced risk of Parkinson's disease [see ref. 152 and references therein) and caffeine in rodent models has protective effects [see ref. 158].

\section{Renal effects - diuretics}

The diuretic and natriuretic effects of caffeine and theophylline are well-known and both have been used to treat edema associated with congestive heart failure [see ref. 159 and references therein]. The diurectic effect seems likely due to antagonism of $\mathrm{A}_{1}$-adenosine receptors [see ref. 160 and references therein). Thus, the highly selective $\mathrm{A}_{1}$-adenosine receptor antagonist CVT-124 (see Fig. 2) appears potentially useful as a diuretic in patients with congestive heart failure [161163]. Blockade of $A_{2 A}$-receptors may be of value in prevention of hepatic cirrhosis [164], and pentoxifylline through phosphodiesterase inhibition can provide renal protection [see ref. 165 and references therein].

\section{Respiratory targets - antitussives, apnea, chronic obstructive pulmonary disease, cystic fibrosis}

The antitussive effects of theobromine are well-known [see ref. 166 and references therein]. The synthetic theobromine analog $\mathrm{CH} 13584$ (see Fig. 9) has been developed with antitussive activity in a guinea pig model [166, 167]. Caffeine and to a lesser extent theophylline are widely used for the apnea that frequently occurs in premature infants, with a minimum of adverse effects [168]. The respiratory stimulatory effects of the xanthine are undoubtedly due to antagonism at adenosine receptors of central respiratory centers [169]. Indeed, in the periphery, caffeine through blockade of $\mathrm{A}_{2}$-adenosine receptors of the carotid body has inhibitory effects on respiration [see ref 170 and references therein]. Chronic obstructive pulmonary disease, an inflammatory disease characterized by airflow obstruction and an alteration in adenosine receptors represents another target for intervention with adenosine receptor agonists or antagonists [see ref. 171 and references therein]. The xanthine 8-cyclopentyl-1,3-dipropylxanthine (DPCPX, see Fig. 2), wellestablished as a potent, selective $\mathrm{A}_{1}$-adenosine receptor antagonist, was shown to stimulate chloride-efflux from cystic fibrosis cells, and thus appeared as a lead compound for therapeutic use in treatment of cystic fibrosis [172]. Further studies demonstrated that the 
effect was not due to antagonism of adenosine receptors, but to activation of so-called cystic fibrosis transmembrane conductance (CFTR) channels by DPCPX and its diallyl analog, 8-cyclohexyl-1,3-diallylxanthine [173]. A wide range of xanthines have been tested for activation of the CFTR channel [174]. Several, including theophylline, enprofylline, pentoxifylline, and IBMX, activated the channel. All were tested at 500 $\mu \mathrm{M}$. In another study, DPCPX was not found to activate whole-cell conductance in cells expressing CFTR channels [175].

\section{Conclusion}

The broad range of effects of caffeine, both as a research tool and as a lead structure for the synthesis and study of diverse xanthine and other related heterocyclics, has had far-reaching impact on biomedical research. Research continues, with a focus in several therapeutic areas in which development of further selective and potent xanthines as antagonists of adenosine receptors and as phosphodiesterase inhibitors may have further impact.

Acknowledgements. The author is indebted to Dr. H. M. Garraffo and to M. Grothe without whom this review could not have been completed. Some of the research cited in this report was funded by the intramural program of NIDDK.

1 Daly, J. W. (1993) Mechanism of action of caffeine. In: Caffeine, Coffee, and Health, Garattini, S. (Ed.), pp. 97 150, Raven, New York.

2 Snyder, S. H., Katims, J. J., Annau, Z., Bruns, R. F. and Daly, J. W. (1981) Adenosine receptors and behavioral actions of methylxanthines. Proc. Natl. Acad. Sci. USA 78, 3260 - 3264.

3 Choi, O. H., Shamim, M. T., Padgett, W. L. and Daly, J. W. (1988) Caffeine and theophylline analogues: correlation of behavioral effects with activity as adenosine receptor antagonists and as phosphodiesterase inhibitors. Life Sci. 43, 387-398.

4 Daly, J. W. (1982) Adenosine receptors: targets for future drugs. J. Med. Chem. 25, 197 - 207.

5 Chasin, M. and Harris, D. N. (1976) Inhibitors and activators of cyclic nucleotide phosphodiesterase. Adv. Cyclic Nucleotide Res. 7, 225-264.

6 Daly, J. W. (1998) Pharmacology of caffeine. In: Handbook of Substance Abuse: Neurobehavioral Pharmacology. Tarter, R. E., Ammerman, R. T. and Ott, P. J. (Eds), pp. 53-68, Plenum, New York.

7 Daly, J. W. (2000) Alkylxanthines as research tools., J. Autonomic Nervous System 81, 44 - 52 .

8 Bonati, M. and Garratini, S. (1984) Interspecies comparison of caffeine disposition. In: Caffeine Perspectives from Recent Research, Dews, P. B. (Ed.), pp. 48 - 56, Springer, New York.

9 Chou C-H. and Waller, G. R. (1980) Possible allelopathic constituents of Coffea arabica. J. Chem. Ecol. 6, 643 - 654.

10 Sattin, A. and Rall, T. W. (1970) The effect of adenosine and adenine nucleotides on the cyclic adenosine $3^{\prime}, 5^{\prime}$-phosphate content of guinea pig cerebral cortex slices. Mol. Pharmacol. $6,13-23$.

11 Shimizu, H., Daly, J. W. and Creveling, C. R. (1969) A radioisotopic method for measuring the formation of adeno- sine 3,5'-cyclic monophosphate in incubated slices of brain. J. Neurochem. 16, 1609 - 1619.

12 DeGubareff, T. and Sleator Jr., W. (1965) Effects of caffeine on mammalian atrial muscle and its interaction with adenosine and calcium. J. Pharmacol. Exp. Ther. 148, $202-214$.

13 Burnstock, G. (1978) A basis for distinguishing two types of purinergic receptors. In: Cell Membrane Receptors for Drugs and Hormones: A Multidisciplinary Approach, Straub, R. W. and Bolis, I., L. (Eds), pp. 107 - 118, Raven, New York.

14 Londos, C., and Wolff, J. (1977) Two distinct adenosinesensitive sites on adenylate cyclase. Proc. Natl. Acad. Sci. USA 74, $5482-5486$.

15 Van Calker, D., Müller, M. and Hamprecht, B. (1979) Adenosine regulates, via two different types of receptors, the accumulation of cyclic AMP in cultured brain cells. J. Neurochem. 33, 999 - 1005.

16 Daly, J. W., Butts-Lamb, P. and Padgett, W. (1983) Subclasses of adenosine receptors in the central nervous system: interaction with caffeine and related methylxanthines. Cell. Mol. Neurobiol. 3, $69-80$.

17 Bruns, R. F., Lu, G. H. and Pugsley, T. A. (1986) Characterization of the $\mathrm{A}_{2}$ adenosine receptor labeled by $\left[{ }^{3} \mathrm{H}\right] \mathrm{NECA}$ in rat striatal membranes. Mol. Pharmacol. 29, 331 - 346.

18 Zhou, Q. Y., Li, C. Y., Johnson, R. A., Stiles, G. L. and Civelli, O. (1992) Molecular cloning and characterization of an adenosine receptor - the $A_{3}$ adenosine receptor. Proc. Natl. Acad. Sci. USA 89, $7432-7436$.

19 Ramkumar, V., Stiles, G. L., Beaven, M. A. and Ali H (1993) The $\mathrm{A}_{3}$ adenosine receptor is the unique adenosine receptor which facilitates release of allergic mediators in mast cells. J. Biol. Chem. 268, 16887 - 16890.

20 Jacobson, K. A., van Galen, P. J.M. and Williams, M. (1992) Adenosine receptors: pharmacology, structure-activity relationships, and therapeutic potential. J. Med. Chem. 35, 407 422.

21 Baraldi, P. G., Cacciari, B., Romagnoli, R., Merighi, S., Varani, K., Borea, P. A. and Spalluto, G. (2000) A denosine receptor ligands: history and perspectives. Med. Res. Rev. 20, $103-128$.

22 Müller, C. E., and Stein, B. (1996) Adenosine receptor antagonists: structures and potential therapeutic applications. Curr. Pharm. Design 2, $501-530$.

23 Hess, S. (2001) Recent advances in adenosine receptor antagonist research. Expert Opin. Ther. Patents 11, 1533 1561.

24 Jacobson, K. A. and Gao Z-G. (2006) Adenosine receptors as therapeutic targets. Nat. Rev. 5, $247-264$.

25 Moro, S., Gao Z-G., Jacobson, K. A. and Spalluto, G. (2006) Progress in the pursuit of therapeutic adenosine receptor antagonists. Med. Res. Rev. 26, 131 - 159.

26 Yuzlenko, O. and Kieć-Kononowicz, K. (2006) Potent adenosine $A_{1}$ and $A_{2 A}$ receptors antagonists: recent developments. Curr. Med. Chem. 13, 3609-3625.

27 Zablocki, J., Elzein, E., and Kalla, R. (2006) $\mathrm{A}_{2 \mathrm{~B}}$ adenosine receptor antagonists and their potential indications. Expert Opin. Ther. Patents 16, $1347-1357$.

28 Beukers, M. W., Meurs, I. and IJzerman, A. P. (2006) Structure-affinity relationships of adenosine $\mathrm{A}_{2 \mathrm{~B}}$ receptor ligands. Med. Res. Rev. 26, $667-698$.

29 Baraldi, P. G., Romagnoli, R., Preti, D., Fruttarolo, F., Carrion, M. D. and Tabrizi, M. A. (2006) Ligands for $\mathrm{A}_{2 \mathrm{~B}}$ adenosine receptor subtype. Curr. Med. Chem. 13, $3467-$ 3482.

30 Akkari, R., Burbiel, J. C., Hockenmeyer, J. and Müller, C. E. (2006) Recent progress in the development of adenosine receptor ligands as anti-inflammatory drugs. Curr. Top. Med. Chem. 6, 1375 - 1399.

31 Legraverend, M. and Grierson, D. S. (2006) The purines: potent and versatile small molecule inhibitors and modulators of key biological targets. Bioorg. Med. Chem. 14, 3987 - 4006.

32 Kiesman, W. F., Zhao, J., Conlon, P. R., Dowling, J. E., Petter, R. C., Lutterodt, F., Jin, X., Smits, G., Fure, M., Jayaraj, A., 
Kim, J., Sullivan, G. and Linden, J. (2006) Potent and orally bioavailable 8-bicyclo[2.2.2] octylxanthines as adenosine $\mathrm{A}_{1}$ receptor antagonists. J. Med. Chem. 49, $7119-7131$.

33 Daly, J. W., Hide, I., Müller, C. E. and Shamim, M. (1991) Caffeine analogs: structure-activity relationships at adenosine receptors. Pharmacology 42, 309-321.

34 Fredholm, B. B., Lindström, K. and Wallman-Johansson, A (1994) Propentofylline and other adenosine transport inhibitors increase the efflux of adenosine following electrical or metabolic stimulation of rat hippocampal slices. J. Neurochem. 62, $563-573$.

35 Parkinson, F. E., Mukherjee, K. and Geiger, J. D. (1996) $\left[{ }^{3} \mathrm{H}\right]$ Adenosine transport in DDT, MF-2 smooth muscle cells inhibition by metabolites of propentofylline. Eur. J. Pharmacol. 308, $97-102$.

36 Jacobson, K. A., Ukena, D., Padgett, W., Daly, J. W. and Kirk, K. L. (1987) Xanthine functionalized congeners as poten ligands at $\mathrm{A}_{2}$-adenosine receptors. J. Med. Chem. 30, 211 214.

37 Vu, C. B., Kiesman, W. F., Conlon, P. R., Lin K-C., Tam, M., Petter, R. C., Smits, G., Lutterodt, F., Jin, X., Chen, L. and Zhang, J. (2006) Tricyclic imidazoline derivatives as potent and selective adenosine $\mathrm{A}_{1}$ receptor antagonists. J. Med. Chem. 49, 7132 - 7139 .

38 Ukena, D., Shamim, M. T., Padgett, W. and Daly, J. W. (1986) Analogs of caffeine: antagonists with selectivity for $\mathrm{A}_{2}$ adenosine receptors. Life Sci. 39, 743 - 750.

39 Seale, T. W., Abla, K. A., Shamim, M. T., Carney, J. M. and Daly, J. W. (1988) 3,7-Dimethyl-1-propargylxanthine: a potent and selective in vivo antagonist of adenosine analogs. Life Sci. $43,1671-1684$.

40 Shamim, M. T., Ukena, D., Padgett, W. L. and Daly, J. W. (1989) Effects of 8-phenyl and 8-cycloalkyl substituents on the activity of mono-, di-, and trisubstituted alkylxanthines with substitution at the 1-, 3- and 7-positions. J. Med. Chem. 32, $1231-1237$

41 Jacobson, K. A., Nikodijevic, O., Padgett, W. L., GalloRodriguez, C., Maillard, M. and Daly, J. W. (1993) 8-(3Chlorostyryl)caffeine (CSC) is a selective $\mathrm{A}_{2}$-adenosine antagonist in vitro and in vivo. FEBS Lett. 323, $141-144$.

42 Nonaka, H., Ichimura, M., Takeda, M., Nonaka, Y., Shimada J., Suzuki, F., Yamaguchi, K. and Kase, H. (1994) KF17837 ((E)-8-(3,4-dimethoxystyryl)-1,3-dipropyl-7-methylxanthine), a potent and selective $\mathrm{A}_{2 \mathrm{~A}}$ receptor antagonist. Eur J. Pharmacol. 267, 335 - 341.

43 Kogyo, K. H., Knutsen, L. J. S. and Weiss, S. M. (2001) KW6002 Kyowa Hakko K09-yo. Curr. Opin. Invest. Drugs 2, $668-673$.

44 Shimada, J., Suzuki, F., Nonaka, H., Ishii, A. and Ichikawa, S. (1992) (E)-1,3-dialkyl-7-methyl-8-(3,4,5-trimethoxystyryl)xanthines: potent and selective adenosine $\mathrm{A}_{2 \mathrm{~A}}$ antagonists. J. Med. Chem. 35, $2342-2345$.

45 Jacobson, K. A., Gallo-Rodriquez, C., Melman, N., Fischer, B., Maillard, M., van Bergen, A., van Galen, P. J.M. and Karton, Y. J. (1993) Structure-activity relationships of 8styrylxanthines as $\mathrm{A}_{2}$-selective adenosine antagonists. J. Med. Chem. 36, $1333-1342$.

46 Williams, M., Francis, J., Ghai, G., Brannwalder, A., Psychoyos, S., Stone, G. A. and Cash, W. D. (1987) Biochemica characterization of the triazoloquinazoline CGS 15943, a novel non-xanthine adenosine antagonist. J. Pharmacol. Exp. Ther. 241, $415-420$.

47 Feoktistov, I., Polosa, R., Holgate, S. T. and Biaggioni, I. (1998) Adenosine $A_{2 B}$ receptors: a novel therapeutic target in asthma. Trends Pharmacol. Sci. 19, $148-153$.

48 Feoktistov, I., Garland, E. M., Goldstein, A. E., Zeng, D., Belardinelli, L., Wells, J. N. and Biaggioni, I. (2001) Inhibition of human mast cell activation with the novel selective adenosine $\mathrm{A}_{2 \mathrm{~B}}$ receptor antagonist 3-isobutyl-8-pyrrolidinoxanthine (IPDX). Biochem. Pharmacol. 62, 1163 - 1173.

49 Hayallah, A. M., Sandoval-Ramírez, J., Reith, U., Schobert, U., Preiss, B., Schumacher, B., Daly, J. W. and Müller, C. E.
(2002) 1,8-Disubstituted xanthine derivatives: synthesis of potent $\mathrm{A}_{2 \mathrm{~B}}$-selective adenosine receptor antagonists. J. Med. Chem. $45,1500-1510$.

50 Kim Y-C., Ji, X., Melman, N., Linden, J. and Jacobson, K. A. (2000) Anilide derivatives of an 8-phenylxanthine carboxylic congener are potent and selective antagonists at human $\mathrm{A}_{2 \mathrm{~B}}$ adenosine receptors. J. Med. Chem. 43, $1165-1172$.

51 Zablock, J., Kalla, R., Perry, T., Palle, V., Varkhedkarv, V., Xiao, D., Piscopio, A., Maa, T., Gimbel, A., Hao, J., Chu, N., Leung, K. and Zeng, D. (2005) The discovery of a selective, high affinity $\mathrm{A}_{2 \mathrm{~B}}$ adenosine receptor antagonist for the potential treatment of asthma. Bioorg. Med. Chem. Lett. 15, $609-612$.

52 Baraldi, P. G., Tabrizi, M.A, Preti, D., Bovero, A., Romagnoli, R., Fruttarolo, F., Zaid, N. A., Moorman, A. R., Varani, K., Gessi, S., Merighi, S. and Borea, P. A. (2004) Design, synthesis and biological evaluation of new heterocyclic xanthine derivatives as highly potent and selective human $\mathrm{A}_{2 \mathrm{~B}}$ adenosine receptor antagonists. J. Med. Chem. 47, 1434 1447.

53 Elzein, E., Kalla, A. R., Li, X., Perry, T., Parkhill, E., Palle, V., Varkhedkar, V., Gimbel, A., Zeng, D., Lustig, D., Leung, K. and Zablocki, J. (2006) Novel 1,3-dipropyl-8-(1-heteroarylmethyl-2H-pyrazol-4-yl)-xanthine derivatives as high affinity and selective $\mathrm{A}_{2 \mathrm{~B}}$ adenosine receptor antagonists. Bioorg. Med. Chem. Lett. 16, $302-306$.

54 Ji X-D., von Lubitz, D., Olah, M. E., Stiles, G. L. and Jacobson, K. A. (1994) Species differences in ligand affinity at central $\mathrm{A}_{3}$-adenosine receptors. Drug Dev. Res. 33, 51 - 59.

55 Priego E-M., von Frijtag Drabbe Kuenzel, J., IJzerman, A. P., Camarasa M-J., Perez- Perez M-J. (2002) Pyrido[2,1-f]purine2,4-dione derivatives as a novel class of highly potent human $\mathrm{A}_{3}$ adenosine receptor antagonists. J. Med. Chem. 45, 3337 3344.

56 Ozola, V., Thorand, M., Diekmann, M., Qurishi, R., Schumacher, B., Jacobson, K. A. and Müller, C. E. (2003) 2Phenylimidazo [2,1-i]purin-5-ones: structure-activity relationships and characterization of potent and selective inverse agonists at human $\mathrm{A}_{3}$ adenosine receptors. Bioorg. Med. Chem. 11, $347-356$.

57 Okamura T, Kurogi, Y., Nishikawa, H., Hashimoto, K., Fujiwara, H., Nagao, Y. (2002) 1,2,4-Triazolo[5,1-i]purine derivatives as highly potent and selective human adenosine $\mathrm{A}_{3}$ receptor ligands. J. Med. Chem. 45, 3703 - 3708.

58 Baraldi, P. G., Preti, D., Tabrizi,, M. A., Fruttarolo, F., Romagnoli, R., Zaid, N. A., Moorman, A. R., Merighi, S., Varani, K. and Borea, P. A. (2005) New pyrrolo[2,1-f]purine2,4-dione and imidazo[2,1-f]purine-2,4-dione derivatives as potent and selective human $\mathrm{A}_{3}$ adenosine receptor antagonists. J. Med. Chem. 48, 4697 - 4701.

59 Varani, K., Merighi, S., Gessi, S., Klotz K-N., Leung, E., Baraldi, P. G., Cacciari, B., Romagnoli, R., Spalluto, G. and Borea, P. A. (2000) $\left[{ }^{3}\right.$ H]MRE 3008F20: a novel antagonist radioligand for the pharmacological and biochemical characterization of human $\mathrm{A}_{3}$ adenosine receptors. Mol. Pharmacol. 57, $968-975$.

60 Sutherland, E. W. and Rall, T. W. (1958) Fractionation and characterization of a cyclic adenine ribonucleotide formed by tissue particles. J. Biol. Chem. 232, 1077 - 1092.

61 Butcher, R. W. and Sutherland, E. W. (1962) Adenine 3',5'phosphate in biological materials., I. Purification and properties of cyclic 3',5'-nucleotide phosphodiesterase and use of this enzyme to characterize adenosine $3^{\prime}, 5^{\prime}$-phosphate in human urine. J. Biol. Chem. 237, $1244-1250$.

62 Beavo, J. A., Rogers, N. L., Crofford, O. B., Hardman, J. G., Sutherland, E. W. and Newman, E. V. (1970) Effects of xanthine derivatives on lipolysis and on adenosine $3^{\prime}, 5^{\prime}$ monophosphate phosphodiesterase activity. Mol. Pharmacol. 6, $597-603$.

63 Polson, J. B., Krzanowski, J. J. and Szentivanyi, A. (1982) Inhibition of a high affinity cyclic AMP phosphodiesterase 
and relaxation of canine tracheal smooth muscle. Biochem Pharmacol. 31, 3403 - 3406.

64 Kramer, G. L. and Wells, J. N. (1980) Xanthines and skeleta muscle: lack of relationship between phosphodiesterase inhibition and increased twitch tension in rat diaphragms. Mol. Pharmacol. 17, 73 - 78 .

65 Beer, B., Chasin, M., Clody, D. E., Vogel, J. R. and Horovitz, Z. P. (1972) Cyclic adenosine monophosphate phosphodiesterase in brain: effect on anxiety. Science 176, $428-430$.

66 Londos, C., Cooper, D. M.F., Schlegel, W. and Rodbell, M. (1978) Adenosine analogs inhibit adipocyte adenylate cyclase by a GTP-dependent process: basis for actions of adenosine and methylxanthines on cyclic AMP production and lipolysis. Proc. Natl. Acad. Sci. USA 75, $5362-5366$.

67 Beavo, J. A. and Reifsnyder, D. H. (1990) Primary sequence of cyclic nucleotide phosphodiesterase isozymes and the design of selective inhibitors. Trends Pharmacol. Sci. 11, 150 155.

68 Ukena, D., Schudt, C. and Sybrecht, G. W. (1993) Adenosine receptor-blocking xanthines as inhibitors of phosphodiesterase isozymes. Biochem. Pharmacol. 45, $847-851$.

69 Fisher, D. A., Smith, J. F., Pillar, J. S., St. Denis, S. H. and Cheng, J. B. (1998) Isolation and characterization of PDE8A a novel human cAMP-specific phosphodiesterase. Biochem. Biophys. Res. Comm. 246, 570 - 577.

70 Kramer, G. L., Garst, J. E., Mitchel, S. S. and Wells, J. N (1977) Selective inhibition of cyclic nucleotide phosphodiesterases by analogues of 1-methyl-3-isobutylxanthine. Biochemistry $16,3316-3321$.

71 Wells, J. N., Garst, J. E. and Kramer, G. L. (1981) Inhibition of separated forms of cyclic nucleotide phosphodiesterase from pig coronary arteries by 1,3-disubstituted and 1,3,8-trisubstituted xanthines. J. Med. Chem. 24, $954-958$.

72 Smellie, F. W., Davis, C. W., Daly, J. W. and Wells, J. N. (1979) Alkylxanthines: inhibition of adenosine-elicited accumulation of cyclic AMP in brain slices and of brain phosphodiesterase activity. Life Sci. 24, $2475-2482$

73 Smellie, F. W., Daly, J. W. and Wells, J. N. (1979) 1-Isoamyl-3 isobutylxanthine: a remarkably potent agent for the potentiation of norepinephrine, histamine, and adenosine-elicited accumulation of cyclic AMP in brain slices. Life Sci. 25,1917 1924

74 Thompson, W. J. (1991) Cyclic nucleotide phosphodiesterase pharmacology, biochemistry and function. Pharmacol. Ther. 51, 13-33.

75 Perry, M. J. and Higgs, G. A. (1998) Chemotherapeutic potential of phosphodiesterase inhibitors. Curr. Opin. Chem. Biol. 2, 472 - 481

76 Jeon, Y. H., Heo Y-S., Kim, C. M., Hyun, Y.-L., Lee, T. G. Ro, S. and Cho, J. M. (2005) Phosphodiesterase: overview of protein structures, potential therapeutic applications and recent progress in drug development. Cell. Mol. Life Sci. 62 , $1198-1220$

77 Castro, A., Jerez, M. J., Gil, C. and Martinez, A. (2005) Cyclic nucleotide phosphodiesterases and their role in immunomodulatory responses: advances in the development of specific phosphodiesterase inhibitors. Med. Res. Rev. 25, $229-224$

78 Wu B-N., Lin R-J., Lo Y-C., Shen K-P., Wang C-C., Lin Y-T. and Chen I-J. (2004) KMUP-1, a xanthine derivative, induces relaxation of guinea-pig isolated trachea: the role of the epithelium, cyclic nucleotides and $\mathrm{K}^{+}$channels. Br. J. Pharmacol. 142,1105-1114.

79 Vemulapalli, S., Walkins, R. W. and Chintala, M. (1996) Antiplatelet and antiproliferative effects of SCH 51866 a novel type 1 and $\mathrm{V}$ phosphodiesterase inhibitor. Cardiovasc Pharmacol. 28, $862-869$.

80 Pissarnitski, D. A., Asberom, T., Boyle, C. D., Chackalamannil, S., Chintala, M., Clader, J. W., Greenlee, W. J., Hu, Y., Kurowski, S., Myers, J., Palamanda, J., Stamford, A. W. Vemulapalli, S., Wang, Y., Wang, P., Wu, P. and Xu, R. (2004) SAR development of polycyclic guanine derivatives targetd to the discovery of a selective PDE5 inhibitor for treatment of erectile dysfunction. Bioorg. Med. Chem. Lett. 14, 1291 1294.

81 Arnold, R., Beer, D., Bhalay, G., Baettig, U., Collingwood, S. P., Craig, S., Devereux, N., Dunstan, A., Glen, A., Gomez, S., Haberthuer, S., Howe, T., Jelfs, S., Moser, H., Naef, R., Nicklin, P., Sandham, D., Stringer, R., Turner, K., Watson, S. and Zurini, M. (2002) 8-Aryl xanthines: potent inhibitors of phosphodiesterase 5. Bioorg. Med. Chem. Lett. 12, $2587-$ 2590.

82 Gibson, A. (2001) Phosphodiesterase 5 inhibitors and nitrergic transmission - from zaprinast to sildenafil. Eur. J. Pharmacol. 411, $1-10$.

83 Bianchi, C. P. (1961) Effects of caffeine on radiocalcium movement in the frog sartorius. J. Gen. Physiol. 44, 845858.

84 Frank, G. B. (1962) Utilization of bound calcium in the action of caffeine and certain multivalent cations on skeletal muscle., J. Physiol. 163, $254-268$.

85 Dyachok, O. and Gylfe, E. (2004) $\mathrm{Ca}^{2+}$-induced $\mathrm{Ca}^{2+}$ release via inositol 1,4,5-trisphosphate receptors is amplified by protein kinase $\mathrm{A}$ and triggers exocytosis in pancreatic $\beta$ cells. J. Biol. Chem. 279, 45455 - 45461.

86 Sei, Y., Gallagher, K. L. and Daly, J. W. (2001) Multiple effects of caffeine on $\mathrm{Ca}^{2+}$ release and influx in human $\mathrm{B}$ lymphocytes. Cell Calcium 29, $149-160$.

87 Gerasimenko, J. V., Flowerdew, S. E., Voronina, S. G., Sukhomlin, T. K., Tepikin, A. V., Petersen, O. H. and Gerasimenko, O. V. (2006) Bile acids induce $\mathrm{Ca}^{2+}$ release from both the endoplasmic reticulum and acidic intracellular calcium stores through activation of inositol triphosphate receptors and ryanodine receptors. J. Biol. Chem. 281, $40154-40163$.

88 Hague, F., Matifat, F., Brûlé, G. and Collin, T. (2000) Caffeine exerts a dual effect on capacitative calcium entry in Xenopus oocytes. Cell. Signal. 12, $31-35$.

89 Luo, D., Sun, H., Xiao, R. P. and Han, Q. (2005) Caffeine induced $\mathrm{Ca}^{2+}$ release and capacitative $\mathrm{Ca}^{2+}$ entry in human embryonic kidney (HEK293) cells. Eur. J. Pharmacol. 509, $109-115$.

90 Müller, C. E. and Daly, J. W. (1993) Stimulation of calcium release by caffeine analogs in pheochromocytoma cells. Biochem. Pharmacol. 46, 1825 - 1829.

91 Cavallaro, R. A., Filocamo, L., Galuppi, A., Galione, A., Brufani, M. and Genazzani, A. A. (1999) Potentiation of cADPR-induced $\mathrm{Ca}^{2+}$-release by methylxanthine analogues. J. Med. Chem. 42, $2527-2534$.

92 Rousseau, E., LaDine, J., Liu Q-L. and Meissner, G. (1988) Activation of the $\mathrm{Ca}^{2+}$ release channel of skeletal muscle sarcoplasmic reticulum by caffeine and related compounds. Arch. Biochem. Biophys. 267, 75 - 86.

93 Pessah, I. N., Stambuk, R. A. and Casida, J. E. (1987) $\mathrm{Ca}^{2+}$ activated ryanodine binding: mechanisms of sensitivity and intensity modulation by $\mathrm{Mg}^{2+}$, caffeine, and adenine nucleotides. Mol. Pharmacol. 31, 232-238.

94 Liu, W. and Meissner, G. (1997) Structure-activity relationship of xanthines and skeletal muscle ryanodine receptor/ $\mathrm{Ca}^{2+}$ release channel. Pharmacology 54, $135-143$.

95 Shi, D., Padgett, W. L. and Daly, J. W. (2003) Caffeine analogs: effects on ryanodine-sensitive calcium-release channels and GABA A $_{\mathrm{A}}$ receptors. Cell. Mol. Neurobiol. 23, 331 347.

96 Sieghart, W. (1992) GABA A receptors: ligand-gated Cl-ion channels modulated by multiple drug-binding sites. Trends Pharmacol. Sci. 13, $446-450$.

97 Korpi, E. R., Gründer, G. and Lüddens, H. (2002) Drug

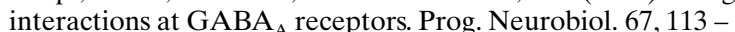
159.

98 Marangos, P. J., Paul, S. M., Parma, A. M., Goodwin, F. K., Syapin, P. and Skolnick, P. (1979) Purinergic inhibition of diazepam binding to rat brain (in vitro). Life Sci. 24, $851-858$.

99 Marangos, P. J., Martino, A. M., Paul, S. M. and Skolnick, P. (1981) The benzodiazepines and inosine antagonize caffeineinduced seizures. Psychopharmacology 72, $269-273$. 
100 Daly, J. W., Padgett, W. L. and Shamim,, M. T. (1986) Analogues of caffeine and theophylline: effect of structural alterations of affinity at adenosine receptors. J. Med. Chem. 29, $1305-1308$.

101 Uneyama, H., Harata, N. and Akaike, N. (1993) Caffeine and related compounds block inhibitory amino acid-gated $\mathrm{C} 1$ currents in freshly dissociated rat hippocampal neurons. Br. J. Pharmacol. 109, 459 - 465.

102 Lindinger, M. I., Willmets, R. G. and Hawke, T. J. (1996) Stimulation of $\mathrm{Na}^{2+}, \mathrm{K}^{+}$-pump activity in skeletal muscle by methylxanthines, evidence and proposed mechanisms. Acta Physiol. Scand. 156, 347 - 353.

103 Taylor, S. C. and Peers, C. (1999) Store-operated $\mathrm{Ca}^{2+}$ influx and voltage-gated $\mathrm{Ca}^{2+}$ channels coupled to exocytosis in pheochromocytoma (PC12) cells. J. Neurochem. 73, $874-$ 880.

104 Schroder, R. L., Jensen, B. S., Strobaek, D., Olesen S-P. and Christophersen, P. (2000) Activation of the human, intermediate-conductance, $\mathrm{Ca}^{2+}$-activated $\mathrm{K}^{+}$channel by methylxanthines. Pflügers Arch. Eur. J. Physiol 440, 809 - 818.

105 Okafor, C., Liao, R., Perreault-Micale,, C., Li, X., Ito, T., Stepanek, A., Doye, A., de Tombe, P. and Gwathmey, J. K. (2003) Mg-ATPase and $\mathrm{Ca}^{2+}$ activated myosin ATPase activity in ventricular myofibrils from non-failing and diseased human hearts - effects of calcium sensitizing agents MCI-154, DPI 201-106, and caffeine. Mol. Cell. Biochem. $245,77-89$.

106 Maia, L. and De Mendouca, A. (2002) Does caffeine intake protect from Alzheimer's disease? Eur., J. Neurol. 9, 377 382.

107 Arendash, G. W., Schleif, W., Rezai-Zadeh, K., Jackson, E. K., Zacharia, L. C., Cracchiolo, J. R., Shippy, D. and Tan, J. (2006) Caffeine protects Alzheimer's mice against cognitive impairment and reduces brain $\beta$-amyloid production. Neuroscience $142,941-952$.

108 Smith, I. F., Hitt, B., Green, K. N., Oddo, S. and LaFerla, F. M. (2005) Enhanced caffeine-induced $\mathrm{Ca}^{2+}$ release in the $3 \times \mathrm{xT}$ AD mouse model of Alzheimer's disease. J. Neurochem. 94, $1711-1718$

109 Bachurin, S. O. (2003) Medicinal chemistry approaches for the treatment and prevention of Alzheimer's disease. Med. Res. Rev. 23, $48-88$.

110 Rosi, S., McGann, K., Hauss-Wegrzyniak, B. and Wonk, G. L. (2003) The influence of brain inflammation upon neuronal adenosine $A_{2 B}$ receptors. J. Neurochem. 86, 220 - 227.

111 Dall'Igna, O. P., Porciúncula, L. O., Souza, D. O., Cunha, R. A. and Lara, D. R. (2003) Neuroprotection by caffeine and adenosine $A_{2 A}$ receptor blockade of $\beta$-amyloid neurotoxicity. Br. J. Pharmacol. 138, 1207 - 1209.

112 Poucher, S. M., Keddie, J. R., Singh, P., Stoggall, S. M., Caulkett, P. W.R., Jones, G. and Collis, M. G. (1995) The in vitro pharmacology of ZM 241385, a potent, non-xanthine, $\mathrm{A}_{2 \mathrm{~A}}$ selective adenosine receptor antagonist. Br. J. Pharmacol. 115, 1096 - 1102.

113 Noble, S. and Wagstaff, A. (1997) Propentofylline. CNS Drugs $8,257-266$

114 Fozard, J. R. and McCarthy,, C. (2002) Adenosine receptor ligands as potential therapeutics in asthma. Curr. Opin. Invest. Drugs 3, 69- 77 .

115 Russo, C., Arcidiacono, G. and Polosa, R. (2006) Adenosine receptors: promising targets for the development of novel therapeutics and diagnostics for asthma. Fund. Clin. Pharmacol. 20,9-19.

116 Horrigan, L. A., Kelly, J. P. and Connor, T. J. (2006) Immunomodulatory effects of caffeine: friend or foe? Pharmacol. Ther. 111, $877-892$.

117 Zablocki, J., Kalla, R., Perry, T., Palle, V., Varkhedkar, V., Xiao, D., Piscopio, A., Maa, T., Gimbel, A., Hao, J., Chu, N., Leung, K. and Zeng, D. (2005) The discovery of a selective, high affinity $\mathrm{A}_{2 \mathrm{~B}}$ adenosine receptor antagonist for the potential treatment of asthma. Bioorg. Med. Chem. Lett. 15, $609-612$.
118 Lin R-J., Wu B-N., Lo Y-C., An L-M., Dai Z-K., Lin Y-T., Tang C-S. and Chen I-J. (2006) A xanthine-based epitheliumdependent airway relaxant KMUP-3 (7-[2-[4-(4-nitrobenzene)piperazinyl] ethyl]-1,3-dimethylxanthine) increases respiratory performance and protects against tumor necrosis factor- $\alpha$-induced tracheal contraction, involving nitric oxide release and expression of cGMP and protein kinase, C. J. Pharmacol. Exp. Ther. 316, 709 - 717.

119 Pascal J-C., Beranger, S., Piuhas, H., Poizot, A. and Désiles JP. (1985) New antihistaminic theophylline and theobromine derivatives. J. Med. Chem. 28, $647-652$.

120 Geraets, L., Moonen, H. J.J., Wouters, E. F.M., Bast, A. and Hageman, G. J. (2006) Caffeine metabolites are inhibitors of the nuclear enzyme poly(ADP-ribose)polymerase- 1 at physiological concentrations. Biochem. Pharmacol. 72, $902-910$.

121 Daly, J. W. and Fredholm, B. B. (1998) Caffeine - an atypical drug of dependence. Drug Alcohol Depend. 51,199 - 206.

122 Kuzmin, A., Johansson, B.,. Gimenez, L., Ögren S-O. and Fredholm, B. B. (2006) Combination of adenosine $A_{1}$ and $A_{2 A}$ receptor blocking agents induces caffeine-like locomotor stimulation in mice. Eur. Neuropsychopharmacol. 16, 129 136.

123 Cauli, O. and Morelli, M. (2005) Caffeine and the dopaminergic system. Behav. Pharmacol. 16, 63 - 77.

124 Fredholm, B. B., Chen J-F., Masino, S. A. and Vaugeois J-M. (2005) Actions of adenosine at its receptors in the CNS: insights from knockouts and drugs. Annu. Rev. Pharmacol. Toxicol. 45, $385-412$.

125 Jacobson, K. A., von Lubitz, D. K.J.E., Daly, J. W. and Fredholm, B. B. (1996) Adenosine receptor ligands: differences with acute versus chronic treatment. Trends Pharmacol. Sci. 17, $108-113$

126 O'Neill, M. and Brown, V. J. (2006) The effect of the adenosine $\mathrm{A}_{2 \mathrm{~A}}$ antagonist KW-6002 on motor and motivational processes in the rat. Psychopharmacology 184, 46- 55.

127 Banfi, C., Sironi, L., De Simoni, G., Gelosa, P., Barcella, S., Perego, C., Gianazza, E., Guerrini, U., Tremoli, E. and Mussoni, L. (2004) Pentoxifylline prevents spontaneous brain ischemia in stroke-prone rats., J. Pharmacol. Exp. Ther. 310, $890-895$

128 Turcani, M., Pavlik, A. and Turcani, P. (2003) Propentofylline rapidly normalizes mitochondrial respiration in a gerbil low flow unilateral forebrain ischemia. Neurosci. Lett. 349, 87 90.

129 Jurczyk, S., Kolaczkowski, M., Maryniak, E., Zajdel, P., Pawlowski, M., Tatarczynska, E., Klodzinska, A., ChojnackaWojcik, E., Bojarski, A. J., Charakchieva-Minol, S., Duszynska, B., Nowak, G. and Maciag, D. (2004) New arylpiperazine $5 \mathrm{HT}_{1 \mathrm{~A}}$ receptor ligands containing the pyrimido[2,1-f]purine fragment: synthesis, in vitro, and in vivo pharmacological evaluation. J. Med. Chem. 47, 2659 - 2666.

130 Kristen, G., Schaefer, A. and Von Schlichtegroll, A. (1986) Fenetylline: therapeutic use, misuse and/or abuse. Drug Alcohol Depend. 17, 259-271.

131 Yao,, L., McFarland, K., Fan, P., Jiang, Z., Ueda, T. and Diamond, I. (2006) Adenosine $A_{2 A}$ blockade prevents synergy between $\mu$-opiate and cannabinoid CB1 receptors and eliminates heroin-seeking behavior in addicted rats. Proc. Natl. Acad. Sci. USA 103, $7877-7882$.

132 Neish, W. J.P. (1988) Xanthines and cancer: An experimental Study of Tumour Inhibition, p. 164. Aberdeen University Press, Aberdeen.

133 Yang, H., Rouse, J., Lukes, L., Lancaster, M., Veenstra, T., Zhou, M., Shi, Y., Park Y-G. and Hunter, K. (2004) Caffeine suppresses metastasis in a transgenic mouse model: a prototype molecule for prophylaxis of metastasis. Clin. Exp. Metastasis 21, 719-735.

134 Lu Y-P., Lou Y-R., Xie J-G., Peng Q-Y., Zhou, S., Lin, Y., Shih, W. J. and Conney, A. H. (2007) Caffeine and caffeine sodium benzoate have a sunscreen effect, enhance UVBinduced apoptosis, and inhibit UVB-induced skin carcinogenesis in SKH-1 mice. Carcinogenesis 28, 199 - 206. 
135 Walters, R. A., Gurley, L. R. and Tobey, R. A. (1974 Effects of caffeine on radiation-induced phenomena associated with cell cycle traverse of mammalian cells Biophys. J. 14, 99-118.

136 Jiang, X., Lim, L. Y., Daly, J. W., Li, A. H., Jacobson, K. A. and Roberge, M. (2000) Structure-activity relationships for G2 checkpoint inhibition by caffeine analogs. Int. J. Oncol. 16, $971-978$.

137 Sarabu, R. and Tilley, J. (2004) Recent advances in therapeutic approaches to type 2 diabetes. Annu. Rep. Med. Chem. 39, $41-56$.

138 Foley, L. H., Wang, P., Dunten, P., Ramsey, G., Gubler M-L. and Wertheimer, S. J. (2003) Modified 3-alkyl-1,8-dibenzylxanthines as GTP-competitive inhibitors of phosphoenolpyruvate carboxykinase. Bioorg. Med. Chem. Lett. 13, $3607-$ 3610.

139 Yang Z-D., Chen, M., Wu, R., MdDuffie, M. and Nadler J-L. (2002) The anti-inflammatory compound lisofylline prevents type I diabetes in non-obese diabetic mice. Diabetologia 45, $1307-1314$

140 Yang, Z., Chen, M., Carter, J. D., Nunemaker, C. S., Garmey, J. C., Kimble, S. D. and Nadler, J. L. (2006) Combined treatment with lisofylline and exendin-4 reverses autoimmune diabetes. Biochem. Biophys. Res. Comm. 344, 1017 - 1022

141 Cui, P., Macdonald, T. L., Chen, M. and Nadler, J. L. (2006) Synthesis and biological evaluation of lisofylline (LSF) analogs as a potential treatment for type 1 diabetes. Bioorg. Med. Chem. Lett. 16, $3401-3405$.

142 Liang, L., Beshay, E. and Prud'homme, G. J. (1998) The phoshodiesterase inhibitors pentoxifylline and rolipram prevent diabetes in NOD mice. Diabetes 47, 570 - 575.

143 Petrie, H. J., Chown, S. E., Belfie, L. M., Duncan, A. M., McLaren, D. H., Conquer, J. A. and Graham, T. E. (2004) Caffeine ingestion increases the insulin response to an oralglucose-tolerance test in obese men before and after weight loss. Am. J. Clin. Nutr. 80, $22-28$

144 Lee, S., Hudson, R., Kilpatrick, K., Graham, T. E. and Ross, R. (2005) Caffeine ingestion is associated with reductions in glucose uptake independent of obesity and type 2 diabetes before and after exercise training. Diabetes Care 28, $566-$ 572.

145 Kurukulasuriya, R., Rohde, J. J., Szczepankiewicz, B. G., Basha, F., Lai, C., Jae H-S., Winn, M., Stewart, K. D. Longenecker, K. L., Lubben, T. W., Ballaron, S. J., Sham, H. L. and von Goldern, T. W. (2006) Xanthine mimetics as potent dipeptidyl peptidase IV inhibitors. Bioorg. Med. Chem. Lett. 16, 6226 - 6230.

146 Sawynok, J. and Yaksh, T. L. (1993) Caffeine as an analgesic adjuvant: a review of pharmacology and mechanisms of action. Pharmacol. Rev. 45, $43-85$.

147 Zhang, W. Y. (2001) A benefit-risk assessment of caffeine as an analgetic adjuvant. Drug Safety 24, $1127-1142$.

148 Abo-Salem, O. M., Hayallah, A. M., Bilkei-Gorzo, A., Filipek, B., Zimmer, A. and Müller, C. E. (2004) Antinociceptive effects of novel $\mathrm{A}_{2 \mathrm{~B}}$ adenosine receptor antagonists. J. Pharmacol. Exp. Ther. 308, 358 - 366.

149 Ahmad, S. and Dray, A. (2004) Novel G protein-coupled receptors as pain targets. Curr. Opin. Invest. Drugs 5, 6770.

150 McGivern, J. G. (2006) Targeting N-type and T-type calcium channels for the treatment of pain. Drug Discovery Today 5 , $245-253$.

151 Eglen, R. M., Hunter, J. C. and Dray, A. (1999) Ions in the fire: recent ion-channel research and approaches to pain therapy. Trends Pharmacol. Sci. 20, 337 - 342 .

$152 \mathrm{Xu}$, K., Bastia, E. and Schwarzschild, M. (2005) Therapeutic potential of adenosine $\mathrm{A}_{2 \mathrm{~A}}$ receptor antagonists in Parkinson's disease. Pharmacol. Ther. 105, $267-310$

153 Hauser, R. A. and Schwarzschild, M. A. (2005) Adenosine $\mathrm{A}_{2 \mathrm{~A}}$ receptor antagonists for Parkinson's disease. Drugs Aging 22, $471-482$.
154 Pinna, A., Wardas, J., Simola, N. and Morelli, M. (2005) New therapies for the treatment of Parkinson's disease: adenosine $\mathrm{A}_{2 \mathrm{~A}}$ receptor antagonists. Life Sci 77, 3259 - 3267.

155 Stasi, M. A., Borsini, F., Varani, K., Vincenzi, F., DiCesare, M. A., Minetti, P., Ghirardi, O. and Carminati, P. (2006) ST 1535: a preferential $\mathrm{A}_{2 \mathrm{~A}}$ adenosine receptor antagonist. Int. J. Neuropyschopharmacol. 9, $575-584$.

156 Johnston, T. H. and Mrotchie, J. M. (2006) Drugs in development for Parkinson's disease: an update. Curr. Opin. Invest. Drugs 7, $25-32$.

157 Vlok, N., Malan, S. F., Castagnoli Jr, N., Bergh, J. J. and Petzer, J. P. (2006) Inhibition of monoamine oxidase B by analogues of the adenosine $A_{2 A}$ receptor antagonist (E)-8-(3chlorostyryl)caffeine (CSC). Bioorg. Med. Chem. 14, 3512 3521.

$158 \mathrm{Xu}, \mathrm{K} ., \mathrm{Xu}, \mathrm{Y}$., Brown-Jermyn, D., Chen J-F., Ascherio, A., Dluzen, D. E. and Schwarzschild, M. A. (2006) Estrogen prevents neuroprotection by caffeine in the mouse 1-methyl4-phenyl-1,2,3,6-tetrahydropyridine model of Parkinson's disease. J. Neurosci. 26, 535 - 541.

159 McColl, J. D., Parker, J. M. and Ferguson, J. K.W. (1956) Evaluation of some 1- and 7-substituted methylated xanthines as diuretics in the rat. J. Pharmacol. Exp. Ther. 118, 162 - 167.

160 Rieg, T., Steigele, H., Schnermann, J., Richter, K., Osswald, H. and Vallon, V. (2005) Requirement of intact adenosine $A_{1}$ receptors for the diuretic and natriuretic action of the methylxanthines theophylline and caffeine. J. Pharmacol. Exp. Ther. 313, 403 - 409.

161 Gellai, M., Schreiner, G. F., Ruffolo, R. R., Fletcher, T., DeWolf, R. and Brooks, D. P. (1998) CVT-124, a novel adenosine $A_{1}$ receptor antagonist with unique diuretic activity. J. Pharmacol. Exp. Ther. 286, 1191 - 1196.

162 Wolff, A. A., Skettino, S. L., Beckman, E. and Belardinelli, L. (1998) Renal effects of BG9719, a specific $A_{1}$ adenosine receptor antagonist, in congestive heart failure. Drug Dev. Res. 45, $166-171$

163 Gottlieb, S. S., Brater, C., Thomas, I., Havranek, E., Bourge, R., Goldman, S., Dyer, F., Gomez, M., Bennett, D., Ticho, B., Beckman, E. and Abraham, W. T. (2002) BG9719 (CVT-124), an $\mathrm{A}_{1}$ adenosine receptor antagonist, protects against the decline in renal function observed with diuretic therapy. Circulation 105, $1348-1353$.

164 Chan, E. S.L., Montesinos, M. C., Fernandez, P., Desai, A., Delano, D. L., Yee, H., Reiss, A. B., Pillinger, M. H., Chen JF., Schwarzschild, M. A., Friedman,, S. L. and Cronstein, B. N. (2006) Adenosine $A_{2 A}$ receptors play a role in the pathogenesis of hepatic cirrhosis. Br. J. Pharmacol. 148, $1144-1155$

165 Lin S-L., Chen R-H., Chen Y-M., Chiang W-C., Tsai T-J. and Hsieh B-S. (2003) Pentoxifylline inhibits platelet-derived growth factor-stimulated cyclin D1 expression in mesangial cells by blocking akt membrane translocation. Mol. Pharmacol. $64,811-822$

166 Usmani, O. S., Belvisi, M. G., Patel, H. J., Crispino, N., Birrell, M. A., Korbonits, M., Korbonits, D. and Barnes, P. J. (2004) Theobromine inhibits sensory nerve activation and cough. FASEB, J. Online 10.1096/fj. 04 - 1990fje. November 17.

167 Kapui, Z., Mikus, E. G., Bence, J., Gerber, K., Boer, K., Korbonits, D., Borsodi, A. and Aranyi, P. (1998) Experimental studies on the antitussive properties of the new xanthine derivative 1H-purine-2,6-dione, 3,7-dihydro-3-methyl-7[(5methyl-1,2,4-oxadiazol-3-yl)methyl]. $3^{\text {rd }}$ communication: Examinations on opioid mechanisms and physical drug dependence. Arzneim.-Forsch./Drug Res. 48, 1147 - 1155.

168 Schmidt, B., Roberts, R. S., Davis, P., Doyle, L. W., Barrington, K. J., Ohlsson, A., Solimano, A. and Tin, W. (2006) Caffeine therapy for apnea of prematurity. New Engl. J. Med. 354, $2112-2121$

169 Horlenius, E. and Lagercrantz, H. (1999) Adenosinergic modulation of respiratory neurons in the neonatal rat brainstem in vitro. J. Physiol. 518, $159-172$. 
170 Conde, S. V., Obeso, A., Vicario, I., Rigual, R., Rocher, A and Gonzalez, C. (2006). Caffeine inhibition of rat carotid body chemoreceptors is mediated by $\mathrm{A}_{2 \mathrm{~A}}$ and $\mathrm{A}_{2 \mathrm{~B}}$ adenosine receptors. J. Neurochem. 98, 616-628.

171 Varani, K., Caramoni, G., Vincenzi, F., Adcock, I., Casolari, P., Leung, E., MacLennan, S., Gessi, S., Morello, S., Barnes, P. J., Ito, K.., Chung, K. F., Cavallesco, G., Azzena, G., Papi, A. and Borea, P. A. (2006) Alteration of adenosine receptors in patients with chronic obstructive pulmonary disease. Am. J. Respir. Crit. Care Med. 173, 398 - 406.

172 Eidelman, O., Guay-Broder, C., van Galen, P. J.M., Jacobson, K. A., Fox, C., Turner, R. J., Cabantchik, Z. I. and Pollard, H. B. (1992) $A_{1}$ adenosine-receptor antagonists activate chloride efflux from cystic fibrosis cells. Proc. Natl. Acad. Sci.USA 89, $5562-5566$
173 Arispe, N., Ma, J., Jacobson, K. A. and Pollard, H. B. (1998) Direct activation of cystic fibrosis transmembrane conductance regulator channels by 8-cyclopentyl-1,3-dipropylxanthine (CPX) and 1,3-diallyl-8-cyclohexylxanthine (DAX). J. Biol. Chem. 273, 5727 - 5734 .

174 Chappe, V., Mettey, Y., Vierfond, J. M., Hanrahan, J. W., Gola, M., Verrier, B. and Becq, F. (1998) Structural basis for specificity and potency of xanthine derivatives as activators of the CFTR chloride channel. Br. J. Pharmacol. 123, 683 - 693.

175 Kunzelmann, K., Briel, M., Schreiber, R., Ricken, S., Nitschke, R. and Greger, R. (1998) No evidence for direct activation of the cystic fibrosis transmembrane conductance regulator by 8-cyclopentyl-1,3-dipropylxanthine. Cell. Physiol. Biochem. 8, 185 - 193.

\section{To access this journal online: http://www.birkhauser.ch/CMLS}

